\title{
MODEL PERILAKU PETANI DALAM ADOPSI SISTEM USAHATANI PADI ORGANIK: PARADOKS SOSIAL-EKONOMI-LINGKUNGAN
}

\author{
Mahra Arari Heryanto, Yayat Sukayat, dan Dika Supyandi \\ Laboratorium Sosiologi dan Penyuluhan Pertanian \\ Program Studi Agribisnis Fakultas Pertanian Universitas Padjadjaran \\ E-mail: mahra.arari@unpad.ac.id ; yayatsukayat
}

\begin{abstract}
ABSTRAK. Usahatani padi dengan sistem organik bukan merupakan hal baru dalam komoditas padi. Pasca Revolusi Hijau yang akhir-akhir ini dirasakan dampak negatifnya, telah banyak menggugah kesadaran petani akan pentingnya sistem pertanian organik yang lebih ramah lingkungan. Namun demikian, peralihan dari sistem usahatani padi yang konvensional menuju ke sistem usahatani padi organik tidak dengan mudah diterima petani. Isu kerusakan ekosistem sawah tidak begitu saja mengubah perilaku petani untuk beralih ke sistem usahatani organik. Minimnya pengetahuan petani akan sistem usahatani padi organik, memperlambat laju peralihan dari usahatani padi konvensional ke usahatani padi oganik. Tantangan menjadi semakin berat tanpa adanya insentif yang berarti bagi para petani padi organik karena perbedaan harga yang diterima petani antara padi organik dan kovensional hanya berbeda sedikit. Alih-alih menambah jumlah petani dan luas lahan sawah yang ditanamai padi dengan sistem organik, petani yang telah menggunakan sistem organik setelah berhitung secara ekonomi banyak yang kembali beralih ke sistem konvensional. Berbagai paradoks persoalan usahatani padi organik ini dianalisis dengan menggunakan pendekatan berpikir sistem (system thinking) dalam suatu struktur diagram kausalitas. Masih diperlukan upaya yang lebih keras dan masif untuk meningkatkan produksi organik dari aspek luas lahan dan petaninya terutama pada aspek sosial dan ekonomi yang secara langsung dialami oleh para petani.
\end{abstract}

Kata kunci: padi organik, berpikir sistem, manajemen pengetahuan petani, lingkungan

\section{MODEL BEHAVIOUR OF FARMERS IN THE ADOPTION OF RICE ORGANIC FARMING SYSTEM : PARADOX OF SOCIO - ECONOMIC - ENVIRONMENTAL}

\begin{abstract}
Organic rice farming system is not a new thing anymore in paddy commodity. Now a day, negative impact of Green Revolution have already construct the awareness of farmers about the importance of organic agricultural system with more environmentally friendly. Nevertheless, the changing from conventional farming system to organic farming system was not easily accepted for the farmers. The decay of rice field ecosystem is not directly change the farming system to organic. The lack of farmers' knowledge in organic farming system, make slow the changing rate down from conventional to organic farming. The challenge more difficult since there was no significant incentive for the farmers because of price that was received by the farmers between organic rice and conventional rice were slightly different only. Instead of develop the number of farmers and organic cultivation area, many farmers that have already applied the organic farming system after make an economic calculation switch return back to the conventional farming system. These many paradoxal farming problems were analyzed using system thingking perspective in a structured causal diagram. It needs greater and massive effort to improve production of organic rice in land cultivation and farmers, ecspecially social and economy aspec that experienced by the farmers directly.
\end{abstract}

Key words: organic rice, system thinking, farmer's knowledge management, environment

\section{PENDAHULUAN}

Pada era Orde Baru Indonesia dikenal sebagai salah satu negara yang berhasil menyediakan cukup beras melalui paket Revolusi Hijau. Penggunaan benih unggul, penggunaan pupuk kimia dan racun hama merupakan paket teknologi yang disebarkan sebagai inovasi baru di sektor pertanian selain pembangunan prasarana pengairan, penelitian dan pengembangan, kredit berbunga rendah serta subsidi sarana produksi pertanian. Dalam jangka pendek upaya tersebut cukup berhasil, namun dalam jangka panjang banyak menimbulkan masalah baru, terutama bertambahnya populasi hama yang menyebabkan semakin seringnya kegagalan panen (Jhamtani, 2008). Kerusakan ekosistem tanah akibat asupan bahan kimia yang berlebihan mulai dikeluhkan oleh sebagian petani, struktur tanah pada musim kemarau akhir-akhir ini menjadi lebih keras dan lebih cepat kering karena kelembababan tanah mudah terangkat.

Fenomena tersebut mendorong sebagian petani di Kabupaten Tasikmalaya untuk mengubah sistem usahataninya untuk tidak lagi menggunakan bahanbahan kimia, terinspirasi oleh kearifan lokal yang banyak mengadopsi sistem pertanian organik. Pada saat yang bersamaan terdapat permintaan beras organik yang cukup besar untuk memenuhi kebutuhan pasar ekspor. Lebih kondusif lagi dukungan pemerintah daerah setempat (Dinas Pertanian) menaruh perhatian yang besar terhadap pengembangan sistem organik melalui program pemerintah.

Pengembangan sistem pertanian padi organik dengan dukungan pasar dan kebijakan Pemda menjadi lebihmasal di Kabupaten Tasikmalaya. Selamatujuh tahun luas lahan padi organik yang berhasil dipanen meningkat 
cukup signifikan. Hal ini merupakan harapan baru bagi petani untuk dapat meningkatkan pendapatannya karena dari sisi harga dan produktivitas padi organik memiliki nilai jual dan produksi per satuan luas lahan yang lebih tinggi dibandingkan dengan padi konvensional.

Perubahan sistem usahatani menjadi organik telah dimulai sejak tahun 2005 silam dan sampai sekarang perkembangan luas penanaman dan pemanenan padi organik terus meningkat. Sebagai suatu perubahan, inovasi dalam penerapan sistem usahatani padi organik pada prakteknya tidak mudah karena berkaitan erat dengan sistem sosial yang sudah terbentuk lama. Kompleksitas sistem yang rumit dengan relasi-relasi yang beraneka ragam terbentuk secara efektif dalam lingkungan yang terus berkembang, sistem usahatani padi konvensional. Struktur sosial pada sistem usahatani padi konvensional didorong ke arah perubahan ketika sebagian petani menyadari dampak kerusakan lingkungan yang diakibatkan oleh pestisida dan pupuk kimia. Dorongan perubahan kemudian semakin besar pada saat banyak aktor mendorong ke arah yang sama, dalam hal ini pasar (permintaan beras organik) dan pemerintah daerah (kebijakan) menuju ke arah yang sama. Pangan organik sebagai pilihan bagi konsumen dan peluang bagi petani menjadi tantangan yang secara sosial mempengaruhi sistem sosial petani padi di Kabupaten Tasikmalaya (Luhman dalam Ritzer, 2011; Canavari et al, 2007; Lauer, 2003)

Merujuk kepada penjelasan di atas, tulisan ini membahas bagaimana perubahan sosial yang terjadi pada sistem sosial petani akibat dari perubahan usahataninya dari sistem konvensional ke sistem organik, apakah sistem usahatani sistem organik mampu diadopsi oleh para petani sistem konvensional? Bagaimana perubahan dari aspek sosio-tekno-ekonomi yang terjadi pada sistem sosial petani?

\section{METODE}

Metode yang digunakan pada penelitian ini adalah kualitatif. Maxwell (1996) menjelaskan bahwa metode kualitatif sangat baik digunakan sesuai dengan tujuannya, di antaranya untuk memahami proses dari suatu peristiwa pada suatu lokasi dan pengembangan penjelasan sebab akibat (causal explanations).

Penelitian kualitatif pada penelitian ini bertujuan untuk menguraikan sistem sosial padi organik yang kompleks, yaitu terdiri dari suatu interaksi jaringan yang saling berpenetrasi antar unsur di dalamnya, mulai dari aspek sosial, ekonomi dan teknologi. Interaksi antar unsur tersebut kemudian membentuk suatu struktur menghasilkan perilaku dalam konteks waktu tertentu yang kemudian disebut sebagai sebuah sistem. Pendekatan berpikir sistem (system thinking) yang digunakan agar mampu mengenali hubungan saling bergantung (interdependent) dan berkaitan (interrelated) dari unsur- unsur dalam suatu sistem (Tasrif, 2004; Parsons, 2007). Guna menggambarkan sistem sosial yang terkait dengan aspek ekonomi dan teknologi, pembahasan dalam makalah ini banyak menggunakan diagram sebab akibat (causal loop diagram).

Data yang digunakan berasal dari berbagai sumber, yaitu data mental, data tertulis, dan data numerik. Data mental sangat penting dalam kajian ini karena terkait dengan keputusan yang diambil oleh petani dan para aktor lainnya, yaitu pemilik lahan dan pedagang gabah. Data mental banyak diperoleh dari wawancara secara mendalam dari para informan yang divalidasi secara triangulasi antar aktor dan data sekunder dimiliki. Para informan merupakan para pelaku yang menjadi petani dan pedagang padi organik yang tergabung dalam Gabungan Kelompok Tani Simpatik di Kabupaten Tasikmalaya.

Data yang bersifat kualitatif menjadi sumber utama dari berbagai informasi yang dihimpun. Data-data tersebut kemudian diformulasikan dalam suatu struktur diagram yang menunjukan hubungan sebab akibat (Forester, 1986; Reyes et al, 2003)

\section{HASIL DAN PEMBAHASAN}

Hasil penelitian menunjukan bahwa salah satu unsur penting yang mempengaruhi kecepatan adopsi sistem usahatani organik secara sosial adalah kepemilikan lahan atas sawah yang diusahakan. Penguasaan dan kepemilikan lahan menjadi penentu keputusan apakah sistem usahatani yang dilakukan akan menggunakan sistem konvensional atau beralih ke sistem organik.

Berdasarkan kepemilikan dan penguasaan lahan sawah tersebut dapat didentifikasi berbagai aktor yang menjadi objek utama dalam menganalisis perubahan perilaku petani, yaitu petani padi konvensional dan petani padi organik. Kedua aktor utama ini merupakan salah satu indikator utama yang digunakan untuk mengukur sejauh mana keberhasilan adopsi inovasi padi organik. Semakin banyak petani padi konvensional beralih ke petani organik, maka adopsi inovasi padi organik semakin baik keberhasilannya.

\section{Adopsi Sistem Usahatani Padi Organik}

Aktor-aktor yang terlibat dalam proses adopsi sistem usahatani padi organik secara umum dibedakan menjadi petani padi yang masih menerapkan sistem konvensional dan petani padi yang sudah menerapakan sistem pertanian organik. Pemilik lahan adalah aktor di belakang layar yang walaupun tidak selalu menjadi petani, tetapi ikut menentukan keputusan mengadopsi sistem pertanian organik. Petani padi dengan sistem usahatani konvensional menjadi titik awal penelitian, bagaimana proses perubahan para petani konvensional beralih dari sistem konvensional ke sistem organik. Proses yang dilalui sampai mengadopsi sistem pertanian organik merujuk kepada tahapan adopsi inovasi yang dijelaskan 
oleh Rogers (1995), yaitu sadar, tertarik, mencoba, mengevaluasi. Secara struktur aktor-aktor dalam proses adopsi inovasi dapat diidentifikasi sebagai berikut (lihat Gambar 1):

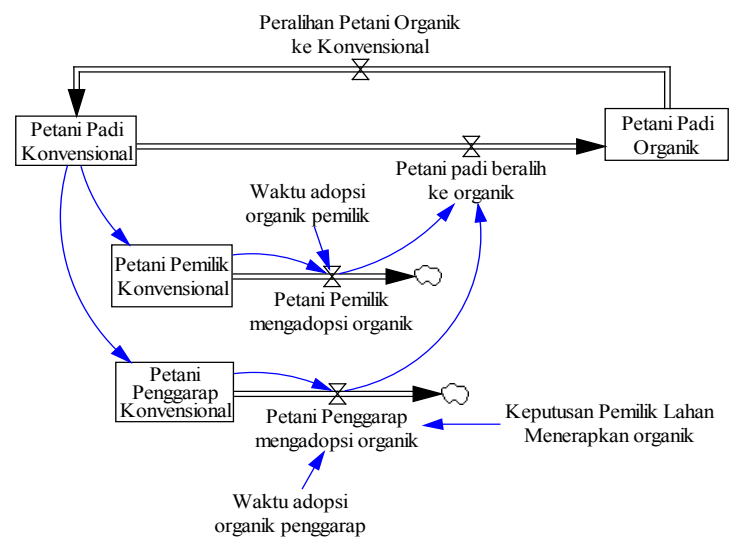

Gambar 1. Aktor-Aktor dalam Proses Adopsi Sistem Usahatani Padi Organik

a) petani padi sistem konvensional

- petani padi pemilik dan penggarap konvensional

- petani padi penggarap konvensional

b) petani padi sistem organik

c) pemilik lahan yang lahannya disewakan kepada penggarap

Petani penggarap dalam proses adopsi usahatani organik bisa menjadi lebih lambat atau lebih cepat karena faktor keputusan pemilik lahan apakah akan mengadopsi sistem organik atau tidak memiliki peran yang sangat besar. Berbeda dengan petani yang lahan diusahakannya adalah milik sendiri, proses pengambilan keputusan berada di petani itu sendiri, sehingga waktu yang dihabiskan selama proses adopsi sangat bergantung kepada proses adopsi yang dilaluinya (sadar-tertarikmencoba-mengevaluasi).

Difusi sebagai proses menyebarkan penemuan kepada masyarakat memerlukan waktu agar dapat diserap oleh masyarakat. Beberapa variabel yang mempengaruhi kecepatan suatu adopsi adalah sebagai berikut (Lauer, 2003; Rogers 1995):

1. Atribut persepsi inovasi: a) keuntungan relatif, b) perbandingan, c) kompleksitas, d) percobaan, dan e) pengamatan

2. Jenis keputusan inovasi: a) pilihan, b) kolektif, dan c) otoritas

3. Saluran komunikasi

4. Sistem sosial sesuai dengan alamnya

5. Agen perubahan

Sistem pertanian organik dapat dianggap sebagai penemuan baru (bagi petani kovensional) karena selama ini sejak era Revolusi Hijau sistem pertanian padi diarahkan kepada pemanfaatan pupuk dan pestisida kimia. Kompleksitas dalam proses perubahan perilaku petani untuk beralih dari pertanian konvensional ke organik cukup rumit, mengingat sistem sosial, jenis keputusan dan persepsi inovasi dipengaruhi oleh banyak unsur dalam sistem pertanian konvensional yang sudah berkembang dan berakumulasi dalam waktu yang sangat lama (empat dekade sejak tahun 1970an sampai sekarang).

Secara historis proses adopsi sistem usahatani padi organik dapat dibagi ke dalam beberapa fase yang dijelaskan dalam beberapa sub-sistem (lihat Gambar 2):

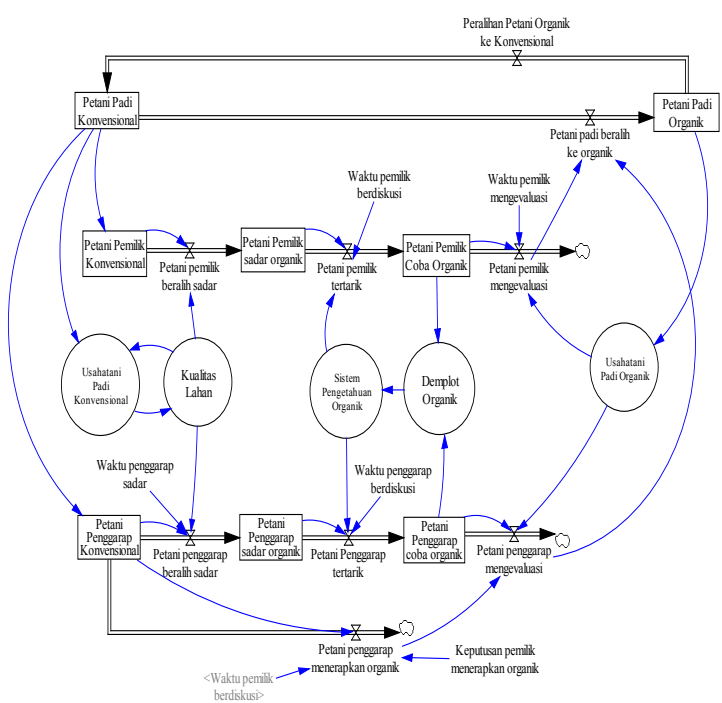

Gambar 2. Diagram Kausal Proses Adopsi Sistem Usaha tani Padi Organik

a) Fase ke-1, usahatani padi konvensional: berdampak kepada kerusakan kualitas lahan yang kemudian mendorong petani untuk menggunakan pupuk kimia sebanyak-banyaknya untuk meningkatkan produktivitas lahan

b) Fase ke-2, kulitas lahan: kerusakan lahan sawah dirasakan dalam waktu yang sangat lama, beberapa dekade setelah Revolusi Hijau digulirkan. Tidak banyak petani yang menyadari dampak kerusakan lahan, hanya sebagian kecil petani yang menyadarinya. Sebagian besar petani merespon penurunan produktivitas dengan meningkatkan dosis pemakaian pupuk dan pestisida kimia tanpa menyadari akar persoalan terjadinya penurunan produktivitas lahan.

c) Fase ke-3, sistem pengetahuan organik dan demplot organik: akumulasi pengetahuan dari pembelajaran demplot usahatani padi organik yang bersifat interpersonal dan kelompok. Pengetahuan mengenai sistem organik ini dapat terus berakumulasi seiring banyaknya pengembangan demplot organik sebagai sarana belajar petani yang tertarik dengan organik. Para petani yang sudah menerapkan sistem usahatani organik membantu menambah akumulasi pengetahuan oraganik dalam kelompok petani.

d) Fase ke-4, usahatani padi organik: usahatani padi organik memiliki beberapa kelemahan salah satunya daricurahan waktuyang diperlukan dalammenjalankan 
usahatani organik. Waktu yang diperlukan usahatani padi organik lebih lama dibandingkan dengan usahatani padi konvensional. Selain itu pula perbedaan harga produk antara gabah organik dan gabah konvensional bagi sebagian besar petani tidak memberikan insentif bagi petani untuk mengadopsi sistem organik. Tahap ini adalah bagian yang paling kritis karena apabila pada tahap ini petani tidak memperoleh manfaat yang nyata dari sisi ekonomi, maka petani akan kembali ke sistem pertanian organik terutama para petani yang menggarap lahan miliknya sendiri. Agak berbeda bagi petani yang hanya berstatus sebagai penggarap, pemilik lahan memiliki otoritas yang cukup kuat untuk menentukan arah usahatani yang diterapkannya.

Status penguasaan dan kepemilikan lahan menentukan keputusan adopsi dari inovasi sistem usaha tani padi organik. Keputusan yang diambil dapat bersifat pilihan, kolektif, maupun otoritas. Bagi petani yang menggarap lahannya sendiri, keputusan mengadopsi inovasi dapat bersifat pilihan dan kolektif. Tahapan adopsi inovasi pada petani pemilik penggarap sangat bergantung kepada persepsi petani itu sendiri. Proses menyadari, tertarik, mencoba dan mengevaluasi dilalui tahapan demi tahapan sampai kepada keputusan untuk mengadopsi sistem usahatani organik. Sebagai suatu pilihan, petani yang menggarap lahannya sendiri bisa saja berhenti pada tahap sebatas menyadari bahwa organik itu penting untuk mengembalikan kualitas lahan yang rusak atau berhenti pada tahap setelah dilakukan ujicoba demonstrasi plot, tetapi tidak dilanjutkan sampai pada keputusan untuk menerapkan usahatani organik di lahan miliknya. Begitu juga dengan kolektifitas, interaksi antar petani memungkinkan terjadinya komunikasi dan pertukaran informasi mengenai sistem usahatani organik sehingga terbangun kolektifitas lembaga yang berakumulasi dalam pengetahuan petani. Jenis informasi dapat bersifat mendorong perubahan dari konvensional menuju organik apabila pengalaman dari percobaan (demplot) sistem organik berjalan dengan baik dengan hasil yang lebih baik dari konvensional, namun dapat juga bersifat menghambat perubahan dari apabila diperoleh pengelaman yang tidak menguntungkan dari usahatani organik. Informasi mengenai keungtungan yang diperoleh dalam suatu kelembagaan akan mempercepat penerimaan dan adopsi suatu inovasi (Randers, 1973; Rogers, 1995).

Sebagai contoh, dari aspek budidaya produktivitas padi organik (7-8 ton per hektar) lebih tinggi dibandingkan dengan produktivitas padi konvensional (5-6 ton per hektar). Namun waktu yang diperlukan untuk mencapai produktivtas yang optimal dari sistem pertanain organik baru dapat tercapai setelah tiga kali masa penanaman sistem organik, bahkan pada awal penanaman menggunakan organik terjadi penurunan produktivitas di bawah rata-rata sistem usahatani konvensional. Secara teknis, tanah memerlukan waktu untuk beradaptasi dengan menetralisir zat kimia yang terkandung dalam tanah dan memperbaiki struktur tanah, sehingga pada masa-masa ini produktivitas menjadi menurun. Apabila tidak dipahami dengan baik, petani yang baru saja memutuskan untuk menerapkan usahatani organik merasa kecewa karena informasi yang diterima tidak sesuai dengan kenyataan yang dialaminya, terlebih lagi arus menanggung kerugian akibat hasil panen yang menurun. Akibatnya petani kembali pada usahatani konvensional karena hasil evaluasi yang dilakukan dari pengalaman yang dialaminya berbeda dengan cerita sukses petani lainnya yang sudah lama menerapkan usahatani organik.

Kondisi tersebut diperkuat secara eksplisit oleh Ketua Gabungan Kelompok Tani Simpatik padi organik di Kabupaten Tasikmalaya Jawa Barat yang menyatakan kewalahan memenuhi permintaan beras ekspor akibat semakin menurunnya produksi karena berkurangnya jumlah petani yang fokus menggarap padi organik. Kemunduran luas panen padi organik terjadi sejak tiga tahun terakhir (2011-2014. Pada 2011, kelompok petani padi organik terdapat di 7 kecamatan sedangkan pada tahun 2014 hanya terdapat di 4 kecamatan saja yakni Kecamatan Manonjaya, Salawu, Cisayong, dan Sukahening.

Penurunan luas panen organik sejak tahun 2011 ini sejalan dengan data historis yang terekam oleh Pemerintah Daerah Kabupaten Tasikmalaya (Gambar 3). Walaupun secara umum terjadi penurunan dari tahun 2011 sampai ke tahun 2013, namun bila dilihat secara tahunan luas panen padi organik mengalami peningkatan dari tahun 2012 ke tahun 2013. Peningkatan ini merupakan momentum yang baik bagi para agen perubahan, khususnya penyuluh, baik swasta maupun pemerintah untuk terus memperluas adopsi inovasi padi organik.

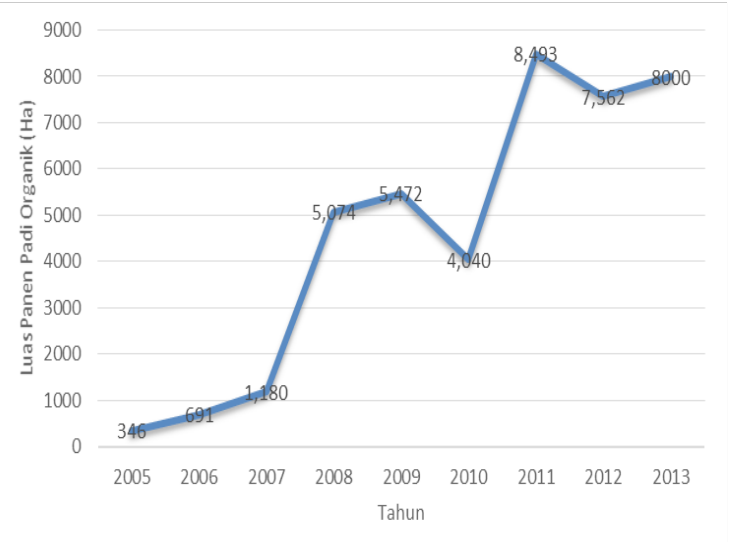

Sumber: Dinas Pertanian Kabupaten Tasikmalaya (2013)

\section{Gambar 3. Luas Panen Padi Organik di Kabupaten Tasikmalaya}

Peran agen perubahan (seperti Penyuluh) menjadi sangat penting bagi penentu keputusan yang bersifat pilihan dan kolektif (Gambar 4). Aktor perubahan harus dapat membuktikan manfaat yang diterima oleh 


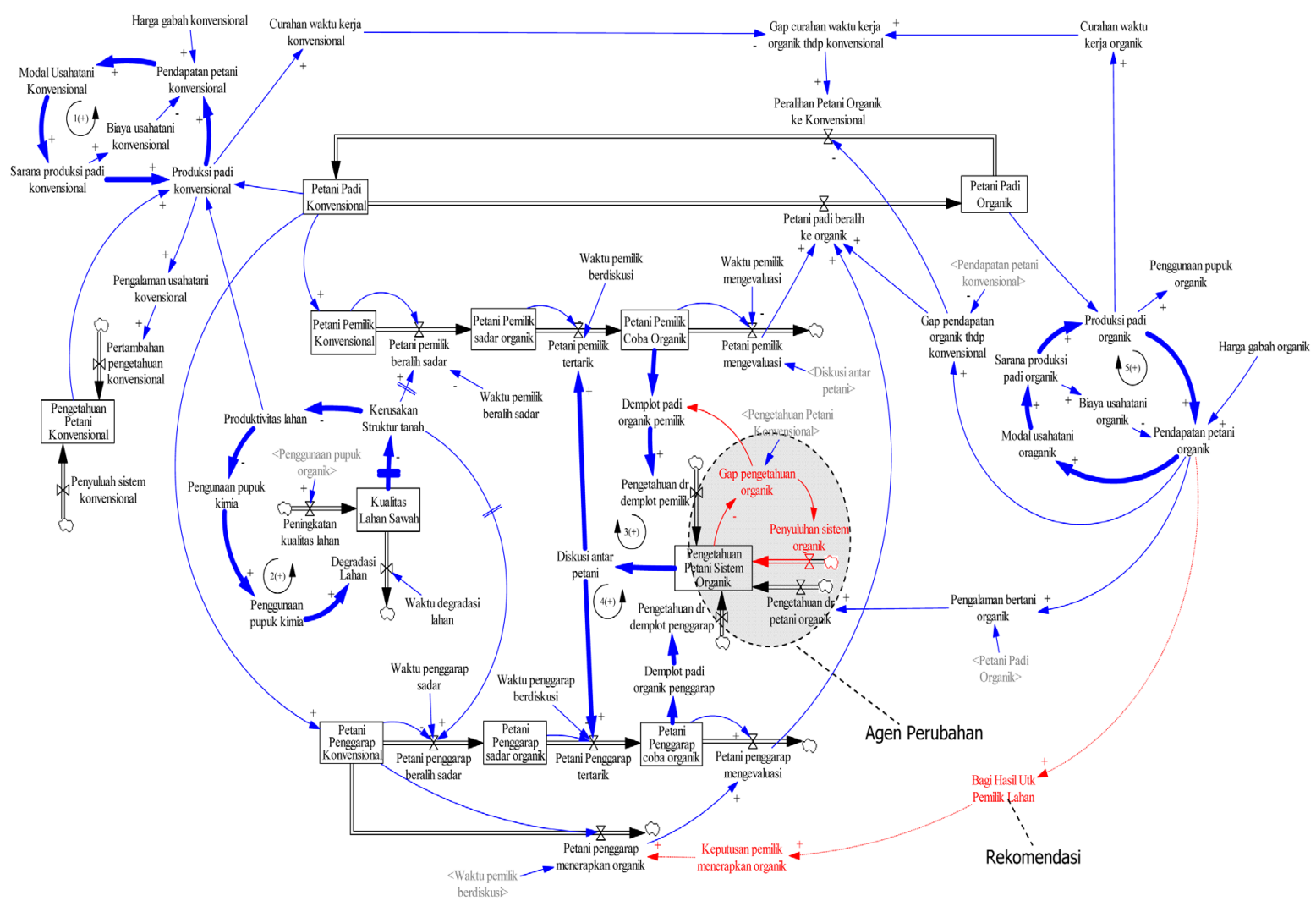

Gambar 4. Struktur Diagram Kausal Adopsi Sistem Usahatani Padi Organik

petani apabila beralih ke sistem organik, tidak saja dari aspek lingkungan tetapi juga secara ekonomi yang menjadi insentif terbesar bagi petani yang mau berubah. Penerimaan kelompok akan menentukan tingkat internalisasi dan adopsi inovasi pada skala yang lebih luas, yaitu masyarakat (Randers, 1973). Oleh karena itu diperlukan aktor dari luar kelompok yang mampu membuktikan dan memperlihatkan keuntungan yang diperoleh apabila diterapkan sistem pertanian organik, sehingga keuntungan (advantage) tersebut dapat disebarkan kepada masyarakat secara internal. Interaksi yang dibangun antara para aktor (petani) yang telah mencoba dan menerapkan sistem usahatani memberikan dorongan yang kuat bagi petani yang telah mencoba dalam tahap evaluasi atau penilaian sehingga petani mau menerapkan sistem organik.

Kondisi tersebut di atas agak berbeda bagi petani yang berstatus menggarap lahan sawah milik orang lain, keputusan inovasinya selain dapat bersifat pilihan dan kolektif juga dapat bersifat otoritas. Keputusan yang bersifat otoritas dapat mengabaikan semua proses adopsi inovasi sebagaimana yang dialami oleh petani pemilik penggarap. Sebagai penerima kuasa menggarap lahan, petani penggarap suka atau tidak, diharuskan mendengar dan melaksanakan keinginan pemilik lahan. Kondisi ini juga menjadi lebih kompleks ketika lahan sawah yang sebelumnya sudah disertifikasi dan diusahakan secara organik diwariskan kepada keturunan petani berikutnya, belum tentu penerima ahli waris selanjutnya menanam dan mengusahakan padi dengan cara organik.
Besarnya otorisasi keputusan adopsi padi organik bergantung kepada besar kecilnya kontribusi ekonomi antara pemilik lahan dengan penggarap dalam mengusahakan padi organik. Apabila pemilik lahan lebih banyak mengeluarkan biaya usahatani lebih besar dibandingkan penggarapnya, maka otoritas pemilik lahan lebih besar dalam menentukan keputusan adopsi.

\section{Paradoks Sosial-Ekonomi-Lingkungan}

Isu lingkungan pada proses adopsi ini menjadi awal terbangunnya kesadaran petani untuk beralih ke sistem usahatani organik. Penggunaan bahan kimia selain meningkatkan produksi pertanian, tetapi juga mengakibatkan ledakan hama karena resistensi terhadap pestisida (Kartodiharjo dan Jhamtani, 2006). Informasi kualitatif dari petani di Kabupaten Tasikmalaya juga memperlihatkan bagaimana struktur tanah yang semakin rusak terutama memasuki musim kemarau dimana tanah lebih cepat kehilangan tingkat kelembabannya sehingga kondisi tanah sangat kering dengan retakan yang lebar dan besar.

Secara sosial, interaksi antara kelompok dan individu pelaku baik itu petani maupun penyuluh yang sudah mengaplikasikan sistem usahatani organik menjadi informasi penting yang bersifat kolektif. Semakin lama informasi tersebut terkumpul, maka akumulasi mengenai pengetahuan organik dalam maysarakat tersebut akan semakin besar. Akumulasi informasi yang menguntungkan (aspek ekonomi dan 
budidaya/produktivitas) mengenai sistem organik menurut Randers (1973) akan meningkatkan penerimaan kelompok terhadap suatu penemuan baru yang dapat terus berkembang di masyarakat. Secara kelembagaan bagi kelompok tani, pengalaman praktek bertani secara organik membantu penambahan informasi mengenai sistem pertanian organik. Pengalaman praktek dan penerimaan usahatani organik apabila digabungkan menjadi kekuatan yang baik dalam membentuk persepsi kelompok dan masyarakat mengenai sistem pertanian organik sehingga proses adopsi dapat semakin meluas.

Pembentukan akumulasi informasi tersebut tidak akan menguntungkan apabila secara teknis dan ekonomi usahatani padi organik tidak lebih menguntungkan dari sistem konvensional. Kedua aspek tersebut (budidaya dan ekonomi) merupakan insentif yang cukup mampu mendorong petani untuk menerapkan usahatani organik. Harapan ini pun tampaknya tidak terlalu banyak menjawab harapan petani karena secara ekonomi harga gabah sistem organik di Kabupaten Tasikmalaya selama ini hanya berbeda 200 rupiah per kilogram dibandingkan dengan gabah sistem konvensional.

Klaim rendahnya biaya produksi padi organik dibandingkan padi konvensional belum mampu mendongkrak penerimaan masyarakat terhadap sistem organik. Asupan sarana produksi yang diproduksi sendiri secara ekonomi memang lebih efisien, tetapi tidak dari curahan waktu tenaga kerja. Curahan waktu tenaga kerja dengan sistem usahatani organik lebih tinggi dibandingkan dengan sistem konvensional karena perawatan dan pemeliharaan yang harus dijalankan secara insentif (layaknya merawat seorang bayi). Ancaman kerusakan lingkungan berdasarkan pembahasan di atas masih belum cukup untuk menambah daya dorong upaya peralihan ke sistem organik, perhitungan ekonomi dan perilaku sosial petani dalam hal ini masih lebih kuat dibandingkan kepedulian lingkungan dalam jangka panjang.

Merujuk kepada uraian tersebut dapat dikatakan isu lingkungan tidak cukup kuat untuk mengubah petani yang sadar akan kerusakan lingkungan menjadi adopter atau beralih ke sistem usahatani organik. Sebagai pembelajaran, aspek sosial dan ekonomi menjadi variabel penentu selain kerusakan lingkungan yang harus dikelola dengan baik agar proses penerimaan dan adopsi organik dapat berjalan dengan baik. Keterkaitan lintas sektor antara aspek sosial, ekonomi dan lingkungan tidak dapat diabaikan, diperlukan kerjasama yang holistik agar tujuan dapat tercapai, yaitu produksi pangan tercapai dengan daya dukung lingkungan yang stabil dalam jangka panjang.

Dibutuhkan suatu inovasi sistem untuk mengembangkan pertanian organik, sehingga tidak hanya sematamata menyebarluaskan usahatani organik agar diadopsi oleh petani. Interaksi menjadi suatu hal yang dominan dalam mengembangkan suatu inovasi, para aktor yang terlibat (pasar, pengetahuan dan pemerintah) tidak dapat dipisahkan agar inovasi yang dikembangkan dapat diadopsi oleh masyarakat (Bruijn et al, 2004).

Pelaku pasar (harga beras organik) dapat menjadi penarik dari sisi permintaan yang merupakan insentif bagi petani. Sementara itu, pemerintah daerah melalui kebijakan berbagai program dapat memperbanyak percobaanpercobaan yang dapat memperkaya pengetahuan usahatani organik di kalangan petani dan petugas penyuluh. Selanjutnya sumber pengetahuan baik dari pengalaman petani maupun hasil riset lembaga sumber pengetahuan dapat dikelola dengan baik dalam suatu manajemen pengetahuan (knowledge management) pertanian organik agar terbentuk akumulasi informasi yang menguntungkan bagi pengembangan usahatani organik.

\section{SIMPULAN}

Sistem usahatani sistem organik mampu diadopsi oleh para petani sistem konvensional dengan berbagai lintasan adopsi yang berbeda. Kecepatan adopsi inovasi usahatani padi organik ditentukan oleh jenis keputusan inovasi. Jenis keputusan inovasi yang bersifat pilihan dan kolektif memerlukan waktu yang lebih lama dibandingkan dengan keputusan inovasi yang bersifat kuasa. Isu kerusakan lingkungan tidak cukup kuat mendorong perubahan untuk mengadopsi usahatani organik, diperlukan pengelolaan yang baik dari aspek sosial dan ekonomi yang banyak mempengaruhi keputusan terutama pada lintasan keputusan inovasi yang bersifat pilihan dan kolektif. Khusus untuk lintasan keputusan inovasi yang bersifat kuasa, aspek sosial menjadi lebih dominan dibandingkan aspek ekonomi karena terkait dengan hak pengambilan keputusan berdasarkan kontribusi ekonomi dalam usahatani padi. Keputusan inovasi tersebut sangat ditentukan oleh sistem sosial petani dalam pengusaan dan kepemilikan lahan.

Perubahan dari aspek sosio-tekno-ekonomi yang terjadi pada sistem sosial petani saling terkait satu dengan yang lain. Aspek ekonomi (harga beras dan biaya produksi) dan teknologi (budidaya dan produktivitas) menjadi insentif yang menentukan perubahan sistem usahatani, apabila insentif yang diterima petani cukup menguntungkan, akan banyak petani yang mau menerapkan usahatani organik. Pada prakteknya, harga beras organik lebih tinggi dibandingkan dengan beras konvensional, sementara itu biaya sarana produksi (pestisida dan pupuk) organik lebih rendah dibandingkan dengan sarana produksi (pestisida dan pupuk) kimia. Namun demikian penggunaan tenaga kerja dan curahan waktu yang lebih intensif pada usahatani organik menjadi hambatan bagi sebagian petani untuk mengadopsi usahatani organik. Dinamika tersebut dialami oleh petani baik yang satatus penguasaannya lahan milik sendiri maupun menggarap milik orang lain. 


\section{DAFTAR PUSTAKA}

Bruijn, H., Voort, H.V.D., Dicke, W., Jong, W.D., and Veeneman, W. 2004. Creating System Innovation. A.A. Balkema Publisher.

Canavari, M. and Olson. K.D. 2007. Organic Food. Consumer's Choices and Farmers' Opportinities. Springer.

Everett, R.M. 1995. Diffusion of Innovation. Fourth Edition. New York: The Free Press.

Forester, JW. 1986. Lessons from System Dynamic Modeling. System Dynamic Review 3 (no. 2, Summer 1987): 136-149. System Dynamic Society.

George, R. 2011. Teori Sosiologi, Dari Sosiologi Klasik Sampai Perkembangan Terakhir Post-modern. Translation from English language edition, entitled Eight Edition Sociological Theory@ Published by McGraw-Hill. Edisi bahasa Indonesia, Yogyakarta: Pustaka Pelajar.
Hira, J. 2008. Lumbung Pangan: Menata Ulang Kebijakan Pangan. Yogyakarta: INSIST Press.

Joseph, M.A. 1996. Qualitative Research Design. An Interactive Approach. California: Sage Publication.

Jørgen, R. 1973. Conceptualizing Dynamic Models of Social Systems: Lessons From Study of Social Change. Disertation Doctor of Philosophy at the Massachsetts Institute of Technology.

Kartodiharjo. H. 2006. Politik Lingkungan dan Kekuasaan di Indonesia. Jakarta: PT. Equinox Publishing Indonesia.

Muhammad, T. 2004. Analisis Kebijakan Meng-gunakan System Dynamics. Bandung: Program Magister Studi Pembangunan Institut Teknologi.

Robert, L.H. 2003. Perspektif Tentang Perubahan Sosial. Judul Asli: Perspective on Social Change, Jakarta: PT. Rineka Cipta.

Talcott, P. 2007. Classical Sociological Theory, 2nd Edition. Malden: Balckwell Publising. 